\title{
THE IMPACT OF ROAD IRREGULARITIES ON THE MOTION OF A MOTOR VEHICLE DURING ACCELERATION
}

\author{
Jarosław Zalewski
}

Warsaw University of Technology, Warsaw, Poland

*E-mail of corresponding author: jaroslaw.zalewski@pw.edu.pl

\section{Resume}

In this paper the selected results concerning the analysis of the phenomena occurring between the road and the wheels of a motor vehicle have been presented. The analysis was prepared for the simulation of the acceleration maneuver with the $100 \%$ (full) throttle along the road with various conditions. The aim of this paper was to analyze whether both the full throttle and the road conditions may affect the forces occurring in the contact area between the wheels of the vehicle and the road, regarding the road conditions and the rear wheel drive of the analyzed vehicle's model.

\author{
Article info \\ Received 22 July 2021 \\ Accepted 16 November 2021 \\ Online 21 January 2022

\section{Keywords:} \\ contact forces between \\ a wheel and a road \\ coefficient of adhesion
}

\section{Introduction}

Acceleration is one of the most common maneuvers in the road traffic. However, if the acceleration pedal is switched to the maximum and the throttle is fully open, then various phenomena can occur, especially in the case of wheel-road cooperation. The ability of a motor vehicle to accelerate is essential, however, depending on the road conditions, may not be fully developed, especially when there are random irregularities on the road and theoretically safe motion of the vehicles may be affected. Multiple researches on motor vehicle dynamics has been a subject of many works, also related to acceleration, e.g. [1] or [2].

The aim of this paper was to present the selected results concerning the wheels-road cooperation during the simulation of motor vehicle's acceleration along with the potential influence of the road irregularities. The motion of the given vehicle's model was disturbed not only by including the randomly uneven road surface, but also through the full throttle during the whole maneuver which, as it will be presented, may have caused the additional phenomena affecting the straightline motion as well as the vertical reaction forces of the road acting on the vehicle's wheels. It is also necessary to examine whether both the road conditions and the rear wheel drive may affect the forces in the contact area between the wheels and the road. The vehicle's model was laden according to the assumptions section and the simulations have been prepared with the use of MSC Adams/Car.

The technical significance of research presented in this paper is based on the understanding of the phenomena between the wheels and the road as well as if the random irregularities can limit the acceleration of a vehicle and to what extent, causing increase in fuel consumption and suspension fatigue at the same time. It seems necessary to upgrade both the vehicle construction and the road infrastructure to optimize the traffic flow, regardless of the traffic control. Uneven roads can decrease the road safety as well, so such a research seems to be a part of the broader scope devoted to the road traffic safety.

However, research on the vehicles' motion does not consider only the straightforward motion, accelerating or braking. The scope of here presented considerations reached beyond the ordinary acceleration and focused mainly on the mechanical aspects of the contact between the wheels and the road.

Among other works, related to the phenomena between the road and the wheels, [3] can be presented as an example of using them for weighing the vehicles. Another example is [4], which presents the considerations on the maintenance features of the anti-skid properties of tires. Some other problems related to wheel - road phenomena have been presented in such works as [5-12].

As for the road irregularities, which can have an influence on motor vehicle dynamics, the work [13] presents the considerations on an index specifying the roughness of a road, the so-called International Roughness Index (IRI), which has been used e.g. as a factor determining the vibrations of a whole vehicle's body. To estimate the road roughness, the measurement of vehicle's acceleration was used in [14]. Other aspects 


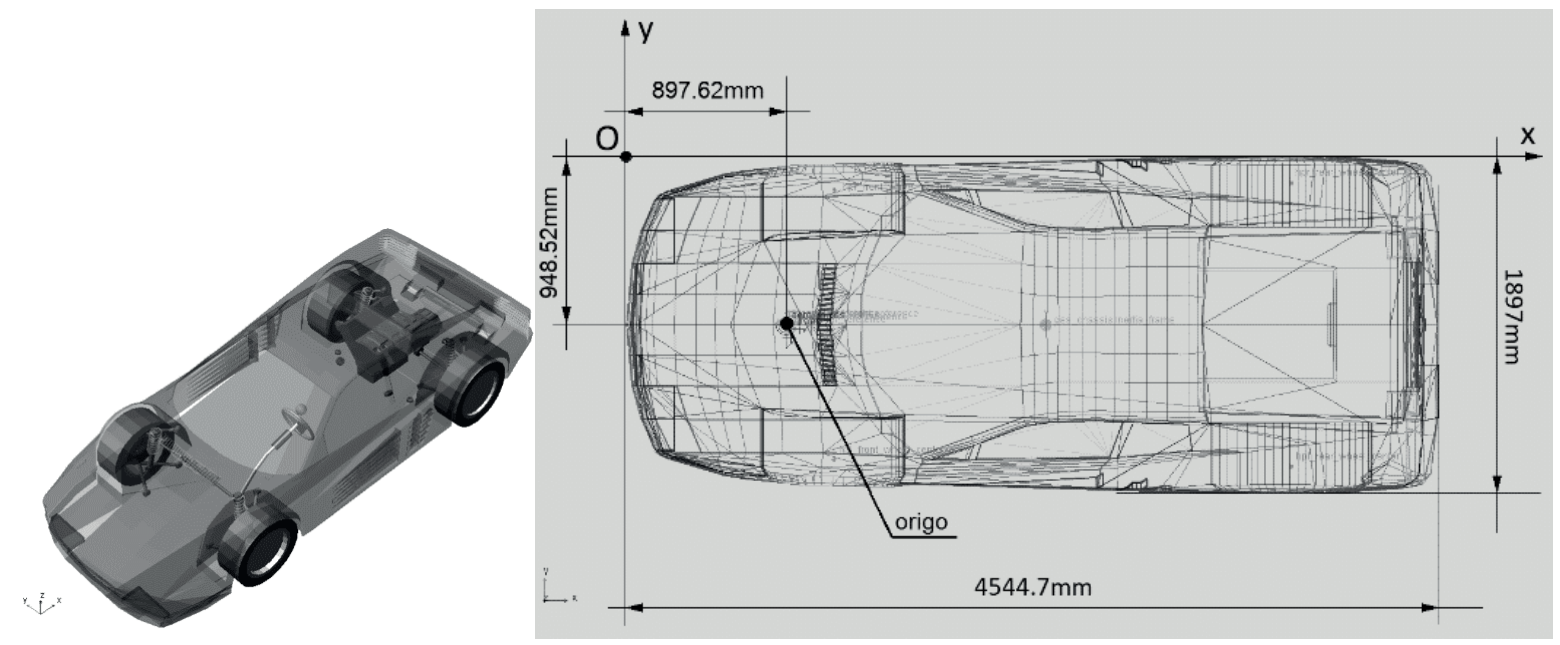

Figure 1 The vehicle's model used in simulations and location of the "origo" point [based on MSC Adams / Car]

in this area consider vibrations caused by the road irregularities [1], the contact between the wheels and the road in the case of a randomly uneven surface [15] and the impact of a wheel on a road border [16]. Another interesting approach may be considerations on aerodynamics of the wheels of a motor vehicle [17].

Research on vehicle dynamics relates not only motor vehicles. For example, in [18] the selected analyses on the rail wheel - track phenomena have been considered.

Research presented in this paper is based on the computer simulations, which have been the tools for many other works, as well, such as [19] or [20].

Considerations on the tire-road phenomena are a part of the research dynamics of motor vehicles, e.g. regarding acceleration [2], dynamics in general ([8], [21$26]$ ), vehicle motion on the icy road [27] or the so-called low friction road [28]. The use of ABS in simulations was considered in [29] and the friction coefficient was estimated, among others in [30-33]. In general, the friction between the wheels and the road has been considered, e.g. in [9-10], [12], [34-36].

\section{Assumptions for the adopted maneuver}

In the presented considerations a double seater vehicle's model has been used (Figure 1) to perform the necessary simulations in Adams/Car. This model has previously been used by the author in [20], however, for different purposes and different maneuvers. The general assumptions regarded the increase in the mass of the vehicle's body (and the whole vehicle at the same time - Table 1) by adding the masses representing a driver, a passenger and a baggage. These additional masses were located in the vehicle's body in such a way that the resulting mass-inertia parameters have been altered (Table 1). New coordinates of the center of mass before and after the loading were calculated by Adams/Car in relation to the so-called "origo" point (Figure 1), which, as described e.g. in [11], is a point moving with the vehicle but placed on the road surface. Similarly, new moments of inertia and new moments of deviation were calculated in relation to the axes intersecting the "origo" and presented in Table 1.

The results presented in Table 1 show that the adopted loading of the vehicle affected mainly the moments of inertia in relation to the $\mathrm{x}$ and $\mathrm{y}$ axes as well as the deviation moment versus the $\mathrm{x}$ and $\mathrm{z}$ axes of the vehicle's coordinate system attached to the so-called "origo" point, i.e. the origin of a system attached to the ground but moving along with the vehicle during the simulations. The moments of inertia and deviation were determined by Adams/Car and presented only to prove that the inertia parameters of a laden passenger vehicle do not alter significantly in relation to the unladen vehicle.

If those parameters were determined versus the center of mass of the vehicle's body, then they would be useless for further analysis because the location of the center of mass was altered after the loading and the remaining parameters (the moments of inertia) would be determined in relation to the altered axes (not the original ones).

The vehicle's double seater model used in this example had the FTIRE (flexible) tires because it had to move along randomly uneven road where the length of a single irregularity can be smaller than the length of the contact plane between the wheel and a road. The springs of the MacPherson column was linear and the dampers non-linear. The vehicle's body was assumed rigid in order to provide the analysis of the vehicle's model as a multibody without deformations considered.

The simulations have been performed for various road conditions. The initial speed was assumed at 20 $\mathrm{km} \cdot \mathrm{h}^{-1}$ and in Table 2 the configurations for regarding the weather (dry or icy surface), the maximum amplitudes of road irregularities (intensity) and the difference or similarity between the road profiles for the left and the right wheels (corrl) have been presented. It can be expected that the most difficult conditions of motion 
Table 1 Mass - inertia parameters of the unladen simulated vehicle model

\begin{tabular}{|c|c|c|c|c|}
\hline & \multicolumn{2}{|c|}{ Unladen vehicle } & \multicolumn{2}{|c|}{ Laden vehicle } \\
\hline & vehicle’s body & $\begin{array}{l}\text { whole } \\
\text { vehicle }\end{array}$ & vehicle’s body & $\begin{array}{l}\text { whole } \\
\text { vehicle }\end{array}$ \\
\hline mass & $995 \mathrm{~kg}$ & $1528 \mathrm{~kg}$ & $1153 \mathrm{~kg}$ & $1686 \mathrm{~kg}$ \\
\hline center of mass location relative to the "origo" & $\begin{array}{c}x_{c}=1.5 \mathrm{~m}, \\
y_{c}=0, \\
z_{c}=0.45 \mathrm{~m}\end{array}$ & $\begin{array}{c}x_{c}=1.75 \mathrm{~m} \\
y_{c}=-0.0014 \mathrm{~m} \\
z_{c}=0.43 \mathrm{~m}\end{array}$ & $\begin{array}{l}x_{c}=1.508 \mathrm{~m}, \\
y_{c}=0.012 \mathrm{~m}, \\
z_{c}=0.452 \mathrm{~m}\end{array}$ & $\begin{array}{c}x_{c}=1.73 \mathrm{~m}, \\
y_{c}=-0.007 \mathrm{~m}, \\
z_{c}=0.435 \mathrm{~m}\end{array}$ \\
\hline $\begin{array}{l}\text { moment of inertia }\left(I_{x}\right) \text { relative to the axis } \\
\text { intersecting the "origo" }\end{array}$ & $401 \mathrm{~kg} \cdot \mathrm{m}^{2}$ & $583 \mathrm{~kg} \cdot \mathrm{m}^{2}$ & $436 \mathrm{~kg} \cdot \mathrm{m}^{2}$ & $618 \mathrm{~kg} \cdot \mathrm{m}^{2}$ \\
\hline $\begin{array}{l}\text { moment of inertia }\left(I_{y}\right) \text { relative to the axis } \\
\text { intersecting the "origo" }\end{array}$ & $2940 \mathrm{~kg} \cdot \mathrm{m}^{2}$ & $6129 \mathrm{~kg} \cdot \mathrm{m}^{2}$ & $3361 \mathrm{~kg} \cdot \mathrm{m}^{2}$ & $6550 \mathrm{~kg} \cdot \mathrm{m}^{2}$ \\
\hline $\begin{array}{l}\text { moment of inertia }(I) \text { relative to the axis } \\
\text { intersecting the „origo" }\end{array}$ & $2838 \mathrm{~kg} \cdot \mathrm{m}^{2}$ & $6022 \mathrm{~kg} \cdot \mathrm{m}^{2}$ & $3225 \mathrm{~kg} \cdot \mathrm{m}^{2}$ & $6409 \mathrm{~kg} \cdot \mathrm{m}^{2}$ \\
\hline $\begin{array}{l}\text { moment of deviation }\left(I_{x y}\right) \text { versus the axes } \\
\text { intersecting the „origo" }\end{array}$ & 0 & $-1.9 \mathrm{~kg} \cdot \mathrm{m}^{2}$ & $2.15 \mathrm{~kg} \cdot \mathrm{m}^{2}$ & $1.95 \mathrm{~kg} \cdot \mathrm{m}^{2}$ \\
\hline $\begin{array}{l}\text { moment of deviation }\left(I_{z x}\right) \text { versus the axes } \\
\text { intersecting the „origo" }\end{array}$ & $671 \mathrm{~kg} \cdot \mathrm{m}^{2}$ & $1160 \mathrm{~kg} \cdot \mathrm{m}^{2}$ & $787 \mathrm{~kg} \cdot \mathrm{m}^{2}$ & $1276 \mathrm{~kg} \cdot \mathrm{m}^{2}$ \\
\hline $\begin{array}{l}\text { moment of deviation }\left(I_{y z}\right) \text { versus the axes } \\
\text { intersecting the „origo" }\end{array}$ & 0 & $-1.3 \mathrm{~kg} \cdot \mathrm{m}^{2}$ & $0.64 \mathrm{~kg} \cdot \mathrm{m}^{2}$ & $0.51 \mathrm{~kg} \cdot \mathrm{m}^{2}$ \\
\hline
\end{tabular}

Table 2 The configurations of the road conditions adopted for the simulations

\begin{tabular}{|c|c|c|c|c|c|}
\hline & Road & Road condition & Intensity & corrl & Initial $V\left[\mathrm{~km}^{\prime} \mathrm{h}^{-1}\right]$ \\
\hline conf 1 & flat & dry & - & - & 20 \\
\hline conf 2 & flat & icy & - & - & 20 \\
\hline conf 3 & uneven & dry & 0.5 & 0.2 & 20 \\
\hline conf 4 & uneven & icy & 0.5 & 0.2 & 20 \\
\hline conf 5 & uneven & dry & 1.0 & 0.2 & 20 \\
\hline conf 6 & uneven & icy & 1.0 & 0.2 & 20 \\
\hline conf 7 & uneven & dry & 1.5 & 0.2 & 20 \\
\hline conf 8 & uneven & icy & 1.5 & 0.2 & 20 \\
\hline
\end{tabular}

would be for the configurations 7 and 8 (dry and icy road with the highest of the adopted amplitudes of the irregularities). It is also worth remembering that the road was randomly uneven in each case except for the configurations 1 and 2. The icy road means that the coefficient of adhesion of the road surface has been established at 0.3 .

Although some works indicate that this coefficient is up to 0.2 for the ideally flat road (e.g. [23-25], [29]), for example in [36] it has been stated that during the braking this coefficient can vary from 0.2 to 0.4 , depending on the air temperature. However, taking into consideration that the assumed road surface is randomly uneven and the ice is not perfectly flat and glassy, the coefficient of adhesion for this work can be assumed at 0.3. No assumptions were made for the tire models though. The coefficient of adhesion used in modeling the phenomena between the tire and a road has been thoroughly examined over the years. The assumed values reflect the average road conditions, which means that the value of this coefficient is 0.8 for a dry and 0.3 for an icy road. It is like the coefficient of friction in the friction theory, but it is usually specified with use of some additional factors, such as dirt on the road.
The acceleration maneuver has been performed with the initial speed of $20 \mathrm{~km} \cdot \mathrm{h}^{-1}$. However, the vehicle started accelerating after the first $2 \mathrm{~s}$. The full throttle was achieved after $0.5 \mathrm{~s}$ as if the driver had only a short period to increase the speed. The full simulation time for each of the configurations, presented in Table 2, was 10 s. Configurations in Table 2 were named as "conf" plus the respective number.

In order to provide the reality of the road conditions, which act as a disturbance to the vehicle's motion, two parameters have been included: intensity and a coefficient specifying the similarity of the road profiles for the left and the right wheels $\left(c_{r l}\right)$. Values of both of these parameters have been presented in Table 2 for the adopted configurations. For the presented example, the corrl coefficient was assumed at 0.2 , which means that the profiles for the left and the right wheels were almost different, which made the maneuver more realistic.

Since intensity specifies the maximum amplitude of the road irregularities when a randomly uneven road profile is considered, it seems worth presenting it graphically. Assuming that the wheel does not lose contact with the road one can obtain the road profiles. In the presented case these profiles have been obtained 
for the selected road section between the 20-th and 95-th meter and for the specific intensity of the irregularities. The reason for selecting only a piece of a covered distance is that not every configuration allowed selection longer section of the road. Such profiles can be measured in real conditions, e.g. by profilometers.

Intensity is used specifically in MSC/Adams Car as a coefficient determining the amplitudes of road irregularities. In the previous research by the author the maximum value of the intensity was adopted at 1 . It is not specified how MSC/Adams relates the intensity to the road profile, although in several tutorials it has been stressed that the road profiles are in accordance with the ISO standards. One of the aims of this paper was to examine whether the greater intensity would produce the more uneven road profile. That is why this coefficient was increased to 1.5 in order to provide even more irregular road.

As for the intensity, its values have been adopted at $0.5,1$ and 1.5 . For the intensity $=0.5$ the maximum amplitudes of the irregularities reached as much as $0.021 \mathrm{~m}$ (Figure 2). On the right-hand part of this figure the power spectral density (psd) of this profile has been determined with the maximum value reaching up to 1.5 for the reciprocal of the wavelength close to 0.1.

For the intensity $=1$ the maximum amplitudes of the irregularities amounted to $0.034 \mathrm{~m}$ (Figure 3). In addition, here the psd of this profile has been determined and its maximum value reached up to 4 but for reciprocal of the wavelength about 1.8 , which means that the irregularities having the wavelength about $0.56 \mathrm{~m}$ could have affected the vehicle's motion at most.
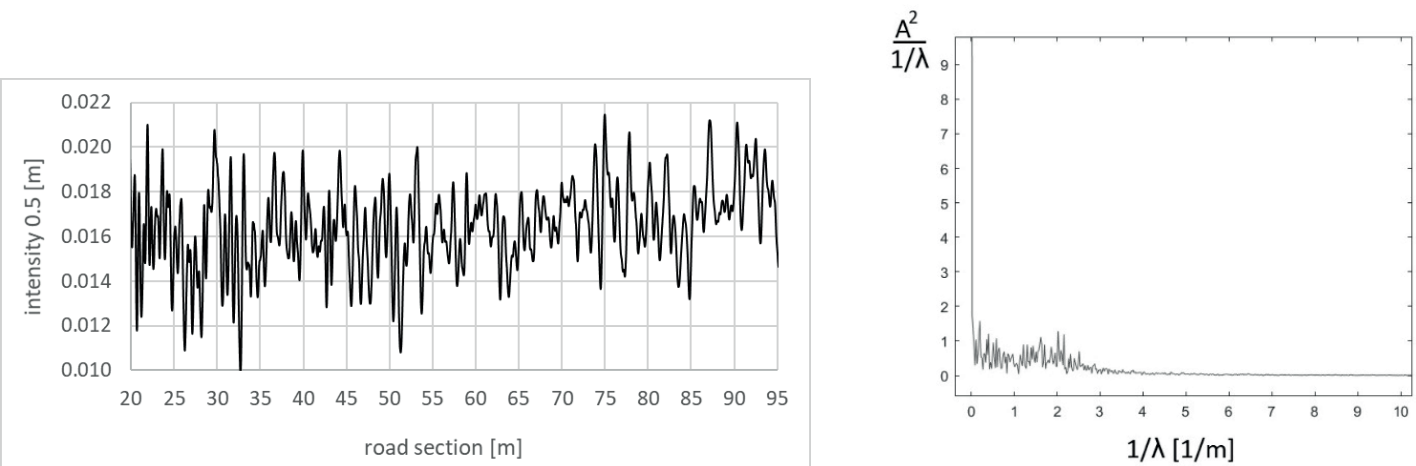

Figure 2 Road profile for the selected road section between the 20-th and 95-th meter at the intensity $=0.5$ and the power spectral density of these irregularities
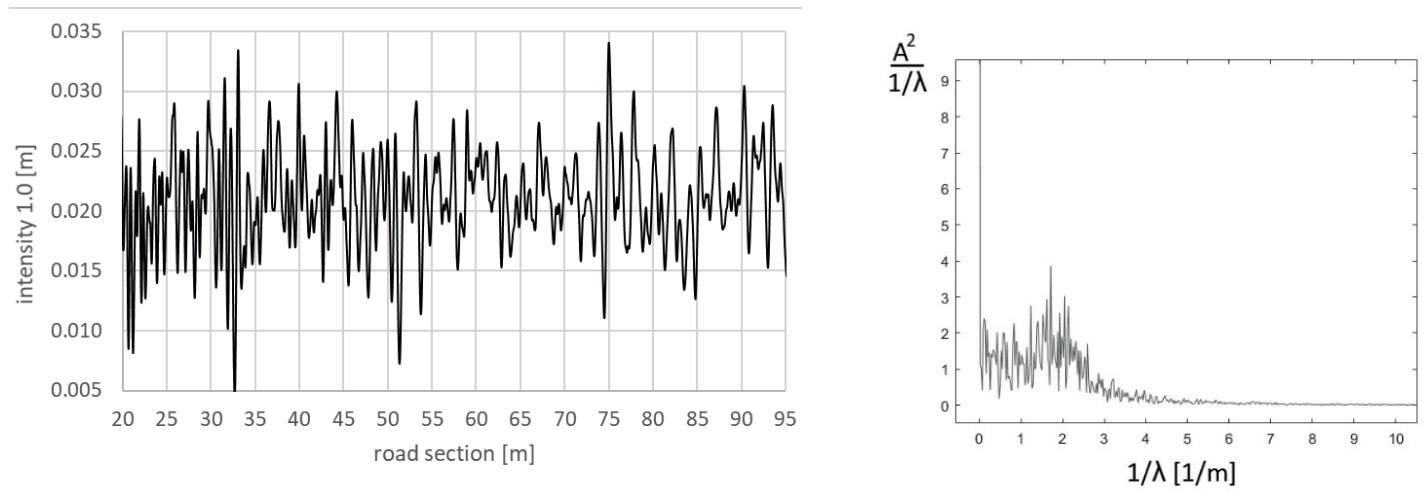

Figure 3 Road profile for the selected road section between the 20-th and 95-th meter at the intensity $=1$ and the power spectral density of these irregularities
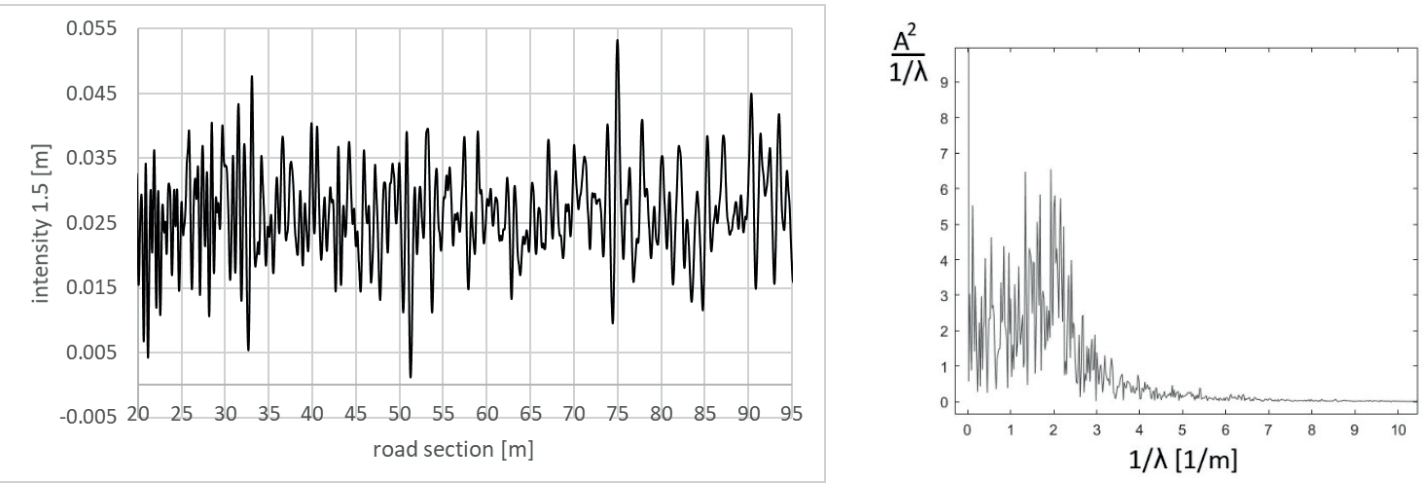

Figure 4 Road profile for the selected road section between the 20-th and 95-th meter at the intensity=1.5 and the power spectral density of these irregularities 


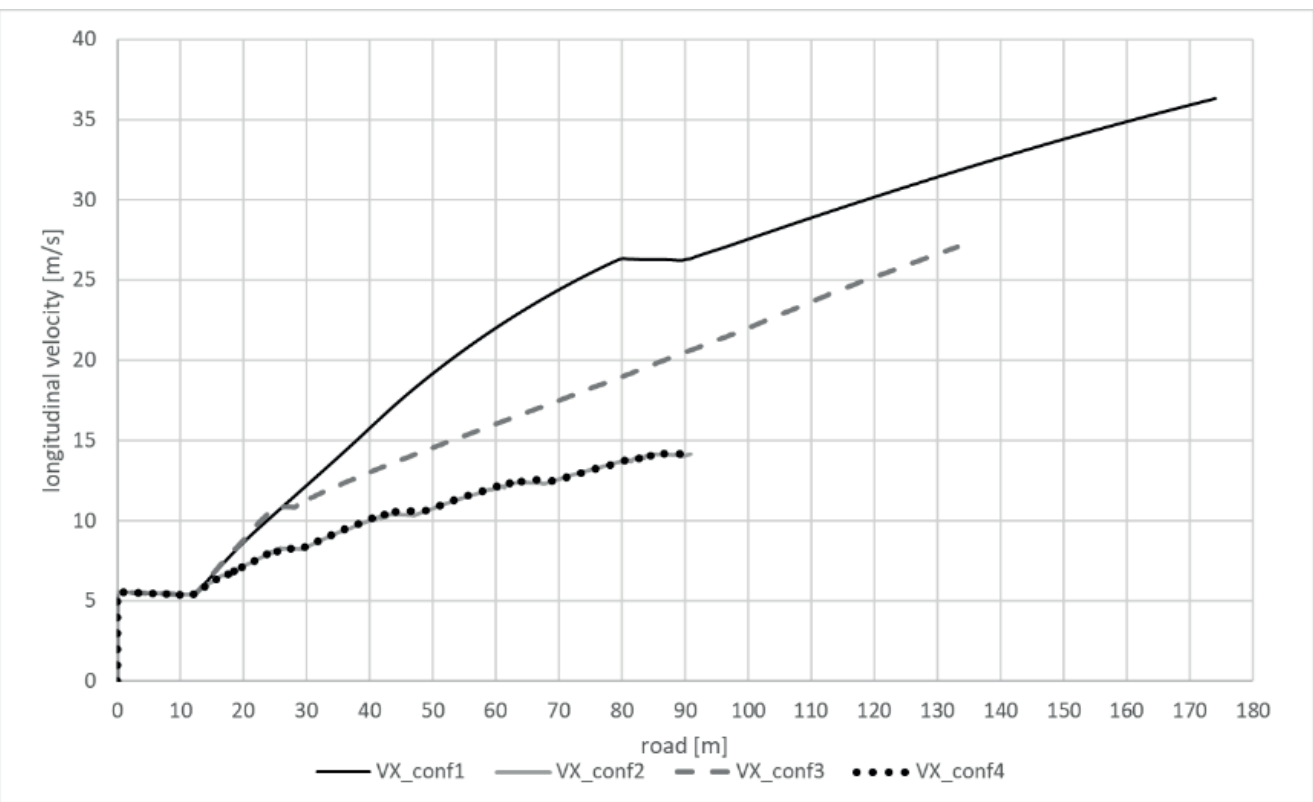

Figure 5 Longitudinal velocity change due to decreasing the speed for configurations 1 to 4

When it comes to the intensity $=1.5$, the maximum values reached up to $0.054 \mathrm{~m}$ (Figure 4). The higher amplitudes produced more interesting psd as well, because the greatest values of the psd for this road profile amounted to approximately 6.5 for the reciprocal of the wavelength equal to approx. 2. This means that the irregularities having the wavelength of approx. 0.5 could have affected the motion along such a road profile.

It also seems important to mention that the discussed maneuver has been performed with the steering set to maintain the straightforward direction. However, one of the aims of this paper was to examine whether the acting disturbances of motion would cause the vehicle to deviate from the potential straightforward direction.

\section{Analysis of the selected results}

The first set of results can be related to the braking nature of a randomly uneven road. In Figures 5 and 6 the longitudinal velocity versus the covered distance has been presented for each of the configurations in Table 2 .

As expected, the higher amplitudes of irregularities, the lesser increase in the longitudinal velocity has been observed. In Figure 5 the results for configurations 1 to 4 have been presented. In the case of the motion along the flat and dry road (conf 1 ) the maximum velocity amounted to about $35 \mathrm{~m} \cdot \mathrm{s}^{-1}$ at the full throttle and the distance was over $170 \mathrm{~m}$. In the case of conf 2 (flat and icy road) the distance was about $85 \mathrm{~m}$ shorter and the velocity reached as much as about $14 \mathrm{~m} \cdot \mathrm{s}^{-1}$. The motion along the uneven road with the intensity 0.5 was characterized by achieving the $135 \mathrm{~m}$ distance with the maximum velocity about $27 \mathrm{~m} \cdot \mathrm{s}^{-1}$ for the conf 3 . Results for the configuration 4 were the same as for configuration 2 . This shows that the randomly uneven road may have a braking nature despite moving at the full throttle. Of course, the icy road provides the additional slip between the road and the wheels, which may affect developing the proper velocity as the wheels rotate faster than when moving straight or slide perpendicularly to the direction of motion.

In Figure 6 the results for configurations 5 to 8 have been presented. In the case of the motion along the uneven and dry road (conf 5, intensity 1.0) the maximum velocity was about $21 \mathrm{~m} \cdot \mathrm{s}^{-1}$ at the full throttle and the vehicle covered almost $120 \mathrm{~m}$ of the distance. In the case of conf 6 (uneven and icy road, intensity 1.0) the distance was for about $30 \mathrm{~m}$ shorter and the velocity reached as much as about $13 \mathrm{~m} \cdot \mathrm{s}^{-1}$. The motion along the uneven road with the intensity 1.5 was characterized by achieving about $95 \mathrm{~m}$ distance with the maximum velocity about $17 \mathrm{~m} \cdot \mathrm{s}^{-1}$ for the configuration 7 . The configuration 8 produced similar results as configuration 6 , which shows that the randomly uneven road with higher amplitudes of the irregularities had even greater influence on both the velocity and the distance.

The possible lateral motion of the vehicle's model in the considered situation can be analyzed based on Figures 7 and 8 where the lateral acceleration has been presented in relation to the covered distance. In addition, here the separate configurations show how the random irregularities along with the dry or icy road surface caused the vehicle to develop the lateral acceleration forcing the vehicle to deviate from the desired straight-line motion (provided no straight-line control is included) as well as ride on the shorter distance than in the case of moving on a dry and flat road (configuration 1, Figure 7).

Lateral acceleration measured, e.g. by accelerometers, can be a factor determining whether a vehicle is subjected to the less or greater lateral 


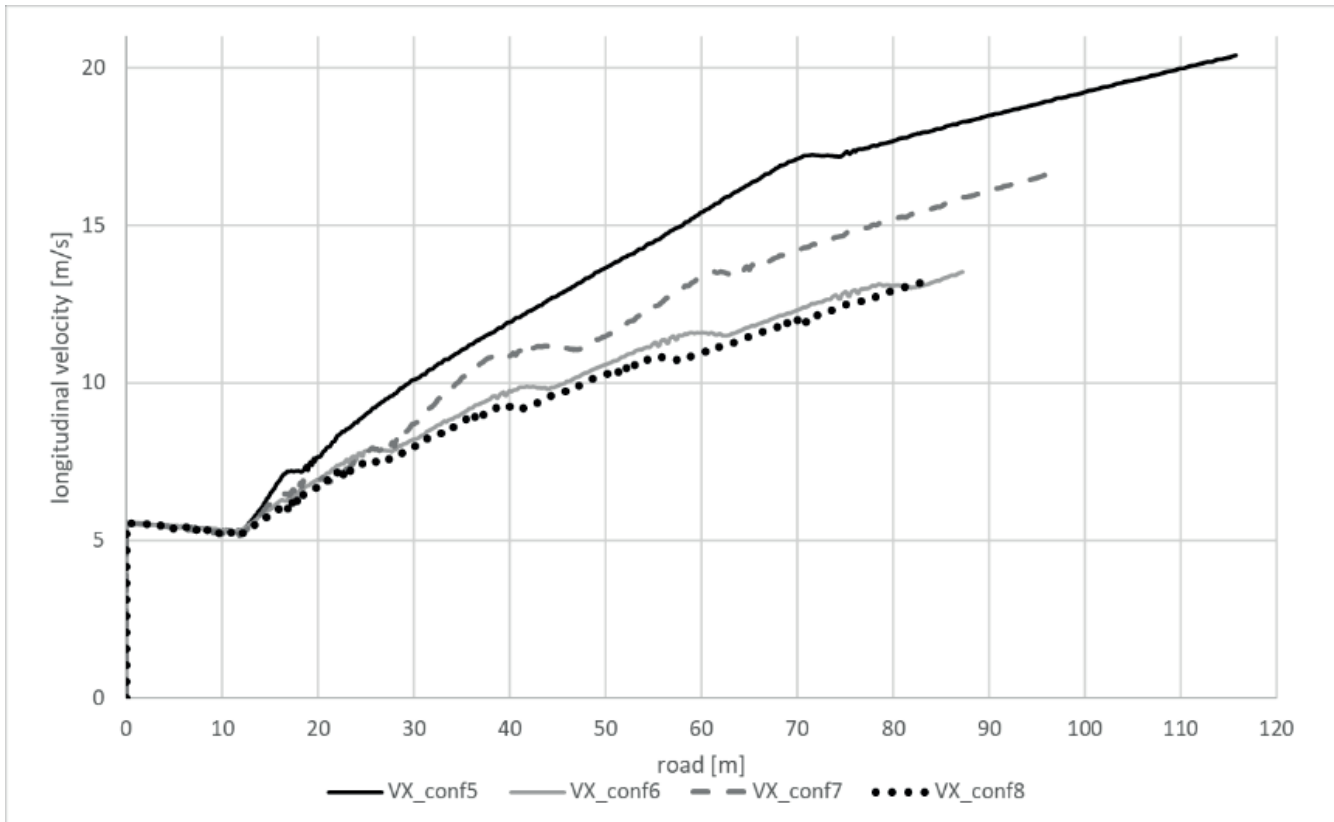

Figure 6 Longitudinal velocity change due to decreasing the speed on an icy road (configurations 5 to 8)
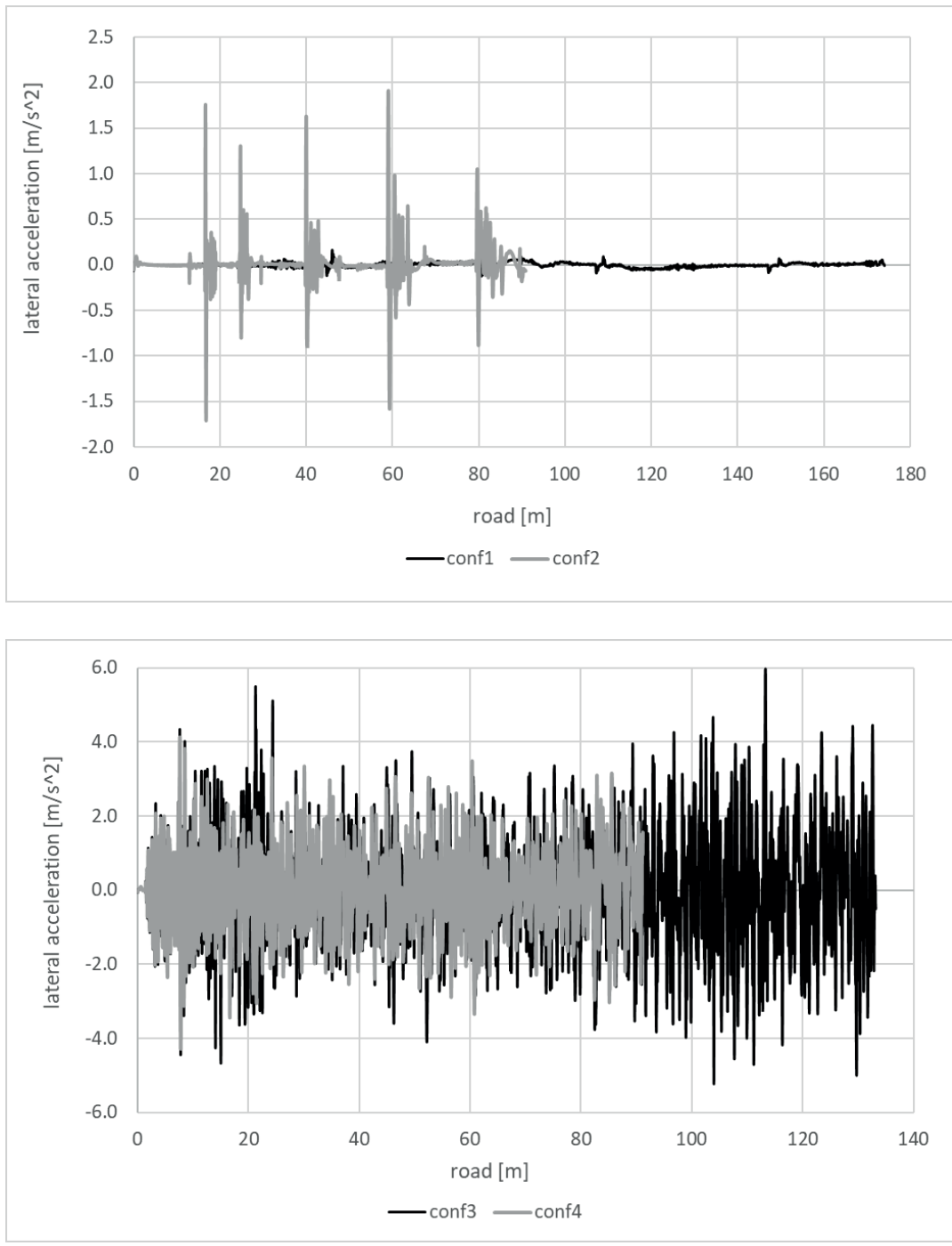

Figure 7 Lateral acceleration versus the covered distance for configurations 1 to 4 

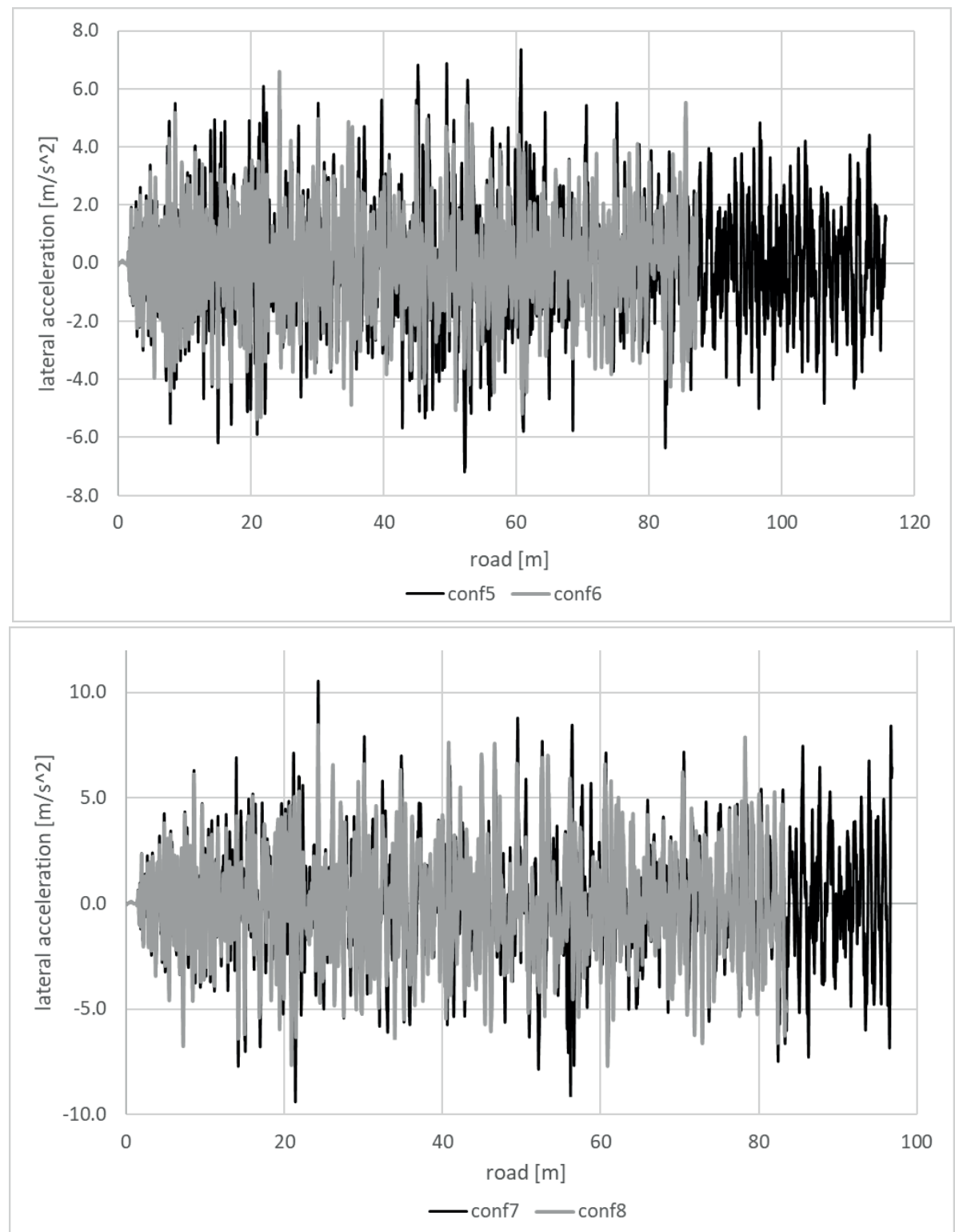

Figure 8 Lateral acceleration versus the covered distance for configurations 5 to 8

phenomena and there is a possibility of a lateral slip between the wheels and the road.

What is interesting is that for the vehicle moving on a flat and randomly uneven road, dry in both cases (configurations 1 and 3, Figure 7) one can observe that the randomly uneven road caused the vehicle to accelerate laterally versus the direction of motion. The amplitudes of this acceleration were higher than for the icy road.

In the case of a motion on a randomly uneven road with the intensity 1.0 and 1.5 (random profiles) the main observation is that the greater intensity of irregularities the greater amplitudes of the lateral acceleration. This can prove that the random irregularities can cause the vehicle do deviate from the straightforward motion and force a driver to perform more reactive driving than in the case of the flat road motion, regardless of the amplitudes of irregularities.

Based on the obtained results, the further part of the presented analysis is concerned with the maximum absolute values of the reaction forces occurring in the contact area between the wheels and the road. This has been presented in Tables 3 to 10 for each of the adopted configurations. In these Tables $F_{X \max }$ means the maximum longitudinal reaction force parallel to the direction of motion, $F_{Y \max }$ is the maximum lateral reaction force and $F_{Z \max }$ is the maximum vertical one. These forces have been determined for each of the vehicle's wheels (LF - left and front, RF - right and front, LR - left and rear, $R R$ - right and rear). This has been done with the use of the two simple equations. Equation (1) specifies an indicator useful to determine the coefficient of adhesion in equation (2), which has been calculated for the maximum values of the obtained reaction forces. This showed the conditions of a maximum adhesion between the wheels and the road. Of course, this coefficient of adhesion gave an information of the phenomena between the road and the wheels for the road surface assumed 
Table 3 The reaction forces of the road on the wheels along with the coefficient of adhesion for the configuration 1

\begin{tabular}{|c|c|c|c|c|c|c|}
\hline & \multicolumn{3}{|c|}{ Left wheel } & \multicolumn{3}{|c|}{ Right wheel } \\
\hline & \multicolumn{3}{|c|}{$\mathrm{LF}$} & \multicolumn{3}{|c|}{$\mathrm{RF}$} \\
\hline & $\mathrm{F}_{\mathrm{X} \max }[\mathrm{N}]$ & $\mathrm{F}_{\mathrm{Ymax}}[\mathrm{N}]$ & $\mathrm{F}_{\mathrm{Zmax}}[\mathrm{N}]$ & $\mathrm{F}_{\mathrm{X} \max }[\mathrm{N}]$ & $\mathrm{F}_{\mathrm{Ymax}}[\mathrm{N}]$ & $\mathrm{F}_{\mathrm{Zmax}}[\mathrm{N}]$ \\
\hline $\max$ & 166.08 & 365.03 & 3874.66 & 167.57 & 634.3 & 3946.36 \\
\hline $\min$ & -22.71 & -604.31 & 2630.67 & -19.57 & -341.95 & 2705.72 \\
\hline$W$ & - & - & 626.72 & - & - & 656.06 \\
\hline \multirow[t]{3}{*}{$\mu$} & - & - & 0.16 & - & - & 0.17 \\
\hline & \multicolumn{3}{|c|}{ LR } & \multicolumn{3}{|c|}{$\mathrm{RR}$} \\
\hline & $\mathrm{F}_{\mathrm{X} \max }[\mathrm{N}]$ & $\mathrm{F}_{\mathrm{Y} \max }[\mathrm{N}]$ & $\mathrm{F}_{\text {Zmax }}[\mathrm{N}]$ & $\mathrm{F}_{\mathrm{X} \max }[\mathrm{N}]$ & $\mathrm{F}_{\mathrm{Ymax}}[\mathrm{N}]$ & $\mathrm{F}_{\text {Zmax }}[\mathrm{N}]$ \\
\hline $\max$ & 691.56 & -717.65 & 5564.94 & 678.17 & 2003.81 & 5653.86 \\
\hline $\min$ & -5289.13 & -2010.29 & 4432.78 & -5400.4 & 672.27 & 4508 \\
\hline$W$ & - & - & 5658.28 & - & - & 5760.17 \\
\hline$\mu$ & - & - & 1.01 & - & - & 1.02 \\
\hline
\end{tabular}

Table 4 The reaction forces of the road on the wheels along with the coefficient of adhesion for the configuration 2

\begin{tabular}{|c|c|c|c|c|c|c|}
\hline & \multicolumn{3}{|c|}{ Left wheel } & \multicolumn{3}{|c|}{ Right wheel } \\
\hline & \multicolumn{3}{|c|}{$\mathrm{LF}$} & \multicolumn{2}{|c|}{$\mathrm{RF}$} & \\
\hline & $\mathrm{F}_{\mathrm{X} \max }[\mathrm{N}]$ & $\mathrm{F}_{\mathrm{Y} \max }[\mathrm{N}]$ & $\mathrm{F}_{\mathrm{Zmax}}[\mathrm{N}]$ & $\mathrm{F}_{\mathrm{X} \max }[\mathrm{N}]$ & $\mathrm{F}_{\mathrm{Y} \max }[\mathrm{N}]$ & $\mathrm{F}_{\mathrm{Zmax}}[\mathrm{N}]$ \\
\hline $\max$ & 317.05 & -38.05 & 3734.42 & 325.09 & 488.95 & 3827.46 \\
\hline $\min$ & -167.93 & -481.68 & 2711.06 & -171.59 & 37.76 & 2795 \\
\hline$W$ & - & - & 576.66 & - & - & 587.16 \\
\hline \multirow[t]{3}{*}{$\mu$} & - & - & 0.15 & - & - & 0.15 \\
\hline & \multicolumn{3}{|c|}{$\mathrm{LR}$} & \multicolumn{3}{|c|}{$\mathrm{RR}$} \\
\hline & $\mathrm{F}_{\mathrm{X} \max }[\mathrm{N}]$ & $\mathrm{F}_{\mathrm{Ymax}}[\mathrm{N}]$ & $\mathrm{F}_{\text {Zmax }}[\mathrm{N}]$ & $\mathrm{F}_{\mathrm{X} \max }[\mathrm{N}]$ & $\mathrm{F}_{\mathrm{Y}_{\max }}[\mathrm{N}]$ & $\mathrm{F}_{\mathrm{Z} \max }[\mathrm{N}]$ \\
\hline $\max$ & 2963.41 & 256.47 & 5783.71 & 3121.27 & 1148.62 & 5856.73 \\
\hline $\min$ & -3357.03 & -1060.93 & 4199.22 & -3434.92 & -267.84 & 4295.07 \\
\hline$W$ & - & - & 3520.68 & - & - & 3621.88 \\
\hline$\mu$ & - & - & 0.61 & - & - & 0.62 \\
\hline
\end{tabular}

to be clean, i.e. without any dust, dirt or other remains, such as leaves, grass, mud, etc.:

$W=\sqrt{F_{X \max }^{2}+F_{Y \max }^{2}}$,

where: $W$ - the indicator (resultant force) used, e.g. in [18] and [27]

and:

$\mu=\frac{W}{F_{Z \max }}$,

where: $\mu$ - the coefficient of adhesion between the wheels and the road.

The obtained results are now considered for the purpose of verifying their correctness. In Table 3 the maximum reaction forces between the wheel and the road have been presented. Based on that, the $\mathrm{W}$ indicator, as well as the adhesion coefficient $(\mu)$, have been determined for the configuration 1 . It is necessary to mention that the amplitudes of the obtained forces reflect the condition of the greatest adhesion and so these forces would provide the so-called ellipses of the adhesion, i.e. the ellipses marking the maximum value of the indicator W, which, according to Equation (1), is the resultant of the tangential reaction forces $F_{X}$ and $F_{Y}$ in the contact plane between the road and the wheels.

Based on that and the Equation (2), it is necessary to notice that values of the determined coefficient of adhesion $(\mu)$ indicate that during the acceleration the front wheels had almost no adhesion while the rear wheels developed the full adhesion (about 1.0), which seems reasonable, provided that the vehicle has a rear drive and the engine located at the back.

In Tables 3 - 10 senses of are presented in accordance with the global coordinate system in Adams/Car. The $F_{X}$ component is positive when its sense is pointed to the back of the vehicle. It is correct since, according to the road wheel dynamics, the longitudinal component of the contact force is pointing in the same direction as velocity. Hence, e.g. in Table 3, the negative values of the $F_{X}$ forces mean that they have the same senses as the direction of velocity. The $F_{Y}$ components have their positive senses pointing to the right of the vehicle and the $F_{Z}$ components are positive when directed vertically 
Table 5 The reaction forces of the road on the wheels along with the coefficient of adhesion for the configuration 3

\begin{tabular}{|c|c|c|c|c|c|c|}
\hline & \multicolumn{3}{|c|}{ Left wheel } & \multicolumn{3}{|c|}{ Right wheel } \\
\hline & \multicolumn{3}{|c|}{$\mathrm{LF}$} & \multicolumn{3}{|c|}{$\mathrm{RF}$} \\
\hline & $\mathrm{F}_{\mathrm{X} \max }[\mathrm{N}]$ & $\mathrm{F}_{\mathrm{Ymax}}[\mathrm{N}]$ & $\mathrm{F}_{\mathrm{Zmax}}[\mathrm{N}]$ & $\mathrm{F}_{\mathrm{X} \max }[\mathrm{N}]$ & $\mathrm{F}_{\mathrm{Ymax}}[\mathrm{N}]$ & $\mathrm{F}_{\mathrm{Zmax}}[\mathrm{N}]$ \\
\hline $\max$ & 995.51 & 723.65 & 4816.76 & 1051.4 & 452.45 & 5134.61 \\
\hline $\min$ & -767.74 & -475.78 & 602.01 & -914.4 & -255.02 & 760.4 \\
\hline$W$ & - & - & 1230.74 & - & - & 1144.62 \\
\hline \multirow[t]{3}{*}{$\mu$} & - & - & 0.26 & - & - & 0.22 \\
\hline & \multicolumn{3}{|c|}{ LR } & \multicolumn{3}{|c|}{$\mathrm{RR}$} \\
\hline & $\mathrm{F}_{\mathrm{X} \max }[\mathrm{N}]$ & $\mathrm{F}_{\mathrm{Y} \max }[\mathrm{N}]$ & $\mathrm{F}_{\text {Zmax }}[\mathrm{N}]$ & $\mathrm{F}_{\mathrm{X} \max }[\mathrm{N}]$ & $\mathrm{F}_{\mathrm{Ymax}}[\mathrm{N}]$ & $\mathrm{F}_{\text {Zmax }}[\mathrm{N}]$ \\
\hline $\max$ & 2390.02 & 341.82 & 7615.85 & 1651.12 & 1223.14 & 7636.4 \\
\hline $\min$ & -7141.09 & -1296.05 & 3012.64 & -6474.63 & -402.63 & 3220.96 \\
\hline$W$ & - & - & 7257.75 & - & - & 6589.15 \\
\hline$\mu$ & - & - & 0.95 & - & - & 0.86 \\
\hline
\end{tabular}

Table 6 The reaction forces of the road on the wheels along with the coefficient of adhesion for the configuration 4

\begin{tabular}{|c|c|c|c|c|c|c|}
\hline & \multicolumn{3}{|c|}{ Left wheel } & \multicolumn{3}{|c|}{ Right wheel } \\
\hline & \multicolumn{3}{|c|}{ LF } & \multicolumn{3}{|c|}{$\mathrm{RF}$} \\
\hline & $\mathrm{F}_{\mathrm{X} \max }[\mathrm{N}]$ & $\mathrm{F}_{\mathrm{Ymax}}[\mathrm{N}]$ & $\mathrm{F}_{\text {Zmax }}[\mathrm{N}]$ & $\mathrm{F}_{\mathrm{X} \max }[\mathrm{N}]$ & $\mathrm{F}_{\mathrm{Ymax}}[\mathrm{N}]$ & $\mathrm{F}_{\text {Zmax }}[\mathrm{N}]$ \\
\hline $\max$ & 867.39 & 254.12 & 5413.73 & 840.36 & 514.98 & 5653.29 \\
\hline $\min$ & -690.17 & -565 & 1481.34 & -651.71 & -104.52 & 642.3 \\
\hline$W$ & - & - & 1035.18 & - & - & 985.6 \\
\hline \multirow[t]{3}{*}{$\mu$} & - & - & 0.19 & - & - & 0.17 \\
\hline & \multicolumn{3}{|c|}{ LR } & \multicolumn{3}{|c|}{$\mathrm{RR}$} \\
\hline & $\mathrm{F}_{\mathrm{X} \max }[\mathrm{N}]$ & $\mathrm{F}_{\mathrm{Ymax}}[\mathrm{N}]$ & $\mathrm{F}_{\text {Zmax }}[\mathrm{N}]$ & $\mathrm{F}_{\mathrm{X} \max }[\mathrm{N}]$ & $\mathrm{F}_{\mathrm{Ymax}}[\mathrm{N}]$ & $\mathrm{F}_{\text {Zmax }}[\mathrm{N}]$ \\
\hline $\max$ & 2917.02 & 223.63 & 7009.33 & 2872.39 & 1157.3 & 7624 \\
\hline $\min$ & -3156.29 & -1000.58 & 2207.86 & -3440.19 & -283.13 & 2865.31 \\
\hline$W$ & - & - & 3311.09 & - & - & 3629.63 \\
\hline$\mu$ & - & - & 0.47 & - & - & 0.48 \\
\hline
\end{tabular}

upwards, which indicates that they are the reaction forces of the road on the wheels.

The components of the contact forces were measured by Adams/Car during each simulation. The measurement method is based on the virtual sensors located at various points of the vehicle's model. Hence, the maximum absolute values of these forces have been determined by the internal measuring system of Adams/Car.

Similarities could be concluded from the results obtained for configuration 2 (Table 4) with the only difference in values of the coefficient of adhesion for the rear wheels, which were a lot lower that in the case of a dry road (about 0.6). One should remember that the motion in the case of configuration 2 occurred along the icy and flat road. As for the front wheel, the adhesion coefficient was 0.15 for both wheels, which was only a bit less than in the case of configuration 1.

In Tables 5 and 6 the results for the motion along a randomly uneven road with the intensity 0.5 have been presented (configurations 3 and 4, respectively). Interestingly, the motion along the dry and randomly uneven road increased the adhesion coefficient for the front wheels and decreased it for the rear wheels, which does not seem unreasonable because the irregularities of the road may have affected the shape of the contact area between the wheels and the road. This observation can be made in relation to configuration 1 , as well.

As for the motion on the randomly uneven and icy road (configuration 4), similar observation can be made in relation to configuration 2 . In addition, here the values of the coefficient of adhesion increased a little on the front wheels and decreased significantly (to about $0.47)$ on the rear wheels.

The next set of results (Tables 7 and 8, configurations 5 and 6 respectively) showed the same tendency in changes of the coefficient of adhesion. Comparing Table 7 with the previous configurations (Tables 3 and 5) one can observe that the discussed coefficient was about 0.25 for the front wheels but varied as in the case of configuration 3, which may be a result of almost different road profiles adopted in simulations.

In Table 8 the value of the coefficient of adhesion increased a little on the front wheels but dropped significantly to 0.37 even though the road conditions 
Table 7 The reaction forces of the road on the wheels along with the coefficient of adhesion for the configuration 5

\begin{tabular}{|c|c|c|c|c|c|c|}
\hline & \multicolumn{3}{|c|}{ Left wheel } & \multicolumn{3}{|c|}{ Right wheel } \\
\hline & \multicolumn{3}{|c|}{$\mathrm{LF}$} & \multicolumn{3}{|c|}{$\mathrm{RF}$} \\
\hline & $\mathrm{F}_{\mathrm{X} \max }[\mathrm{N}]$ & $\mathrm{F}_{\mathrm{Ymax}}[\mathrm{N}]$ & $\mathrm{F}_{\mathrm{Zmax}}[\mathrm{N}]$ & $\mathrm{F}_{\mathrm{X} \max }[\mathrm{N}]$ & $\mathrm{F}_{\mathrm{Y} \max }[\mathrm{N}]$ & $\mathrm{F}_{\text {Zmax }}[\mathrm{N}]$ \\
\hline $\max$ & 1470 & 768 & 6700 & 1430.18 & 597.07 & 6868 \\
\hline $\min$ & -1040 & -555 & -903 & -1040.78 & -263.67 & -1142.13 \\
\hline$W$ & - & - & 1658.53 & - & - & 1549.8 \\
\hline \multirow[t]{3}{*}{$\mu$} & - & - & 0.25 & - & - & 0.23 \\
\hline & \multicolumn{3}{|c|}{ LR } & \multicolumn{3}{|c|}{$\mathrm{RR}$} \\
\hline & $\mathrm{F}_{\mathrm{X} \max }[\mathrm{N}]$ & $\mathrm{F}_{\mathrm{Y} \max }[\mathrm{N}]$ & $\mathrm{F}_{\mathrm{Zmax}}[\mathrm{N}]$ & $\mathrm{F}_{\mathrm{X} \max }[\mathrm{N}]$ & $\mathrm{F}_{\mathrm{Y}_{\max }}[\mathrm{N}]$ & $\mathrm{F}_{\text {Zmax }}[\mathrm{N}]$ \\
\hline $\max$ & 2020.85 & 454.97 & 8935.27 & 1431.57 & 1146.32 & 9400 \\
\hline $\min$ & -5761.58 & -1135.63 & 974.61 & -7167.79 & -368.95 & 1422.89 \\
\hline$W$ & - & - & 5872.43 & - & - & 7258.87 \\
\hline$u$ & - & - & 0.66 & - & - & 0.77 \\
\hline
\end{tabular}

Table 8 The reaction forces of the road on the wheels along with the coefficient of adhesion for the configuration 6

\begin{tabular}{|c|c|c|c|c|c|c|}
\hline & \multicolumn{3}{|c|}{ Left wheel } & \multicolumn{3}{|c|}{ Right wheel } \\
\hline & \multicolumn{3}{|c|}{$\mathrm{LF}$} & \multicolumn{3}{|c|}{$\mathrm{RF}$} \\
\hline & $\mathrm{F}_{\mathrm{X} \max }[\mathrm{N}]$ & $\mathrm{F}_{\mathrm{Y} \max }[\mathrm{N}]$ & $\mathrm{F}_{\mathrm{Z} \max }[\mathrm{N}]$ & $\mathrm{F}_{\mathrm{X} \max }[\mathrm{N}]$ & $\mathrm{F}_{\mathrm{Ymax}}[\mathrm{N}]$ & $\mathrm{F}_{\text {Zmax }}[\mathrm{N}]$ \\
\hline $\max$ & 1151.32 & 274.8 & 6703.52 & 1244 & 562.24 & 7218.32 \\
\hline $\min$ & -795.15 & -677.93 & -52.36 & -803.24 & -282.38 & -836.12 \\
\hline$W$ & - & - & 1336.08 & - & - & 1365.14 \\
\hline \multirow[t]{3}{*}{$\mu$} & - & - & 0.2 & - & - & 0.19 \\
\hline & \multicolumn{3}{|c|}{ LR } & \multicolumn{3}{|c|}{$\mathrm{RR}$} \\
\hline & $\mathrm{F}_{\mathrm{X} \text { max }}[\mathrm{N}]$ & $\mathrm{F}_{\mathrm{Y} \max }[\mathrm{N}]$ & $\mathrm{F}_{\text {Zmax }}[\mathrm{N}]$ & $\mathrm{F}_{\mathrm{X} \max }[\mathrm{N}]$ & $\mathrm{F}_{\mathrm{Ymax}}[\mathrm{N}]$ & $\mathrm{F}_{\text {Zmax }}[\mathrm{N}]$ \\
\hline $\max$ & 2534.82 & 210.04 & 8560.18 & 2589.23 & 1036.44 & 8487.15 \\
\hline $\min$ & -3012.9 & -1051.38 & 46.2 & -2927.14 & -205.27 & 92.08 \\
\hline$W$ & - & - & 3191.07 & - & - & 3105.21 \\
\hline$\mu$ & - & - & 0.37 & - & - & 0.37 \\
\hline
\end{tabular}

Table 9 The reaction forces of the road on the wheels along with the coefficient of adhesion for the configuration 7

\begin{tabular}{|c|c|c|c|c|c|c|}
\hline & \multicolumn{3}{|c|}{ Left wheel } & \multicolumn{3}{|c|}{ Right wheel } \\
\hline & \multicolumn{3}{|c|}{$\mathrm{LF}$} & \multicolumn{3}{|c|}{$\mathrm{RF}$} \\
\hline & $\mathrm{F}_{\mathrm{X} \text { max }}[\mathrm{N}]$ & $\mathrm{F}_{\mathrm{Y} \max }[\mathrm{N}]$ & $\mathrm{F}_{\mathrm{Zmax}}[\mathrm{N}]$ & $\mathrm{F}_{\mathrm{X} \text { max }}[\mathrm{N}]$ & $\mathrm{F}_{\mathrm{Ymax}}[\mathrm{N}]$ & $\mathrm{F}_{Z_{\max }}[\mathrm{N}]$ \\
\hline $\max$ & 1708.59 & 672.7 & 7734.13 & 2062.91 & 862.01 & 7878.1 \\
\hline $\min$ & -1109.6 & -848.5 & -1036.14 & -1142.47 & -642.7 & -1248.35 \\
\hline$W$ & - & - & 1907.7 & - & - & 2235.8 \\
\hline \multirow[t]{3}{*}{$\mu$} & - & - & 0.25 & - & - & 0.28 \\
\hline & \multicolumn{3}{|c|}{ LR } & \multicolumn{3}{|c|}{$\mathrm{RR}$} \\
\hline & $\mathrm{F}_{\mathrm{X} \max }[\mathrm{N}]$ & $\mathrm{F}_{\mathrm{Ymax}}[\mathrm{N}]$ & $\mathrm{F}_{\text {Zmax }}[\mathrm{N}]$ & $\mathrm{F}_{\mathrm{X} \max }[\mathrm{N}]$ & $\mathrm{F}_{\mathrm{Y} \max }[\mathrm{N}]$ & $\mathrm{F}_{\text {Zmax }}[\mathrm{N}]$ \\
\hline $\max$ & 3363.75 & 439.21 & 10251.4 & 3470.2 & 1149.82 & 10013.7 \\
\hline $\min$ & -8049.54 & -1408.92 & -178.43 & -9764.48 & -525.67 & -234.52 \\
\hline W & - & - & 8171.91 & - & - & 9831.95 \\
\hline$\mu$ & - & - & 0.8 & - & - & 0.98 \\
\hline
\end{tabular}

changed only in a matter of the irregularities. The intensity adopted at 1.0 caused the coefficient on the driven wheels to drop significantly, which proves that the more uneven road, the harder for the driven wheels to maintain the adhesion.

The last set of results concerned the harshest road conditions with the intensity of the road adopted at 1.5. Interestingly, on a dry road the coefficient of adhesion increased its value up to 0.8 on the left and 0.98 on the right wheel. It seems strange that the greatest amplitudes caused the driven (rear) wheels to adhere more than in the case of the lower irregularities (intensity 1.0). This coefficient for the front wheels remained at the same level as before. 
Table 10 The reaction forces of the road on the wheels along with the coefficient of adhesion for the configuration 8

\begin{tabular}{|c|c|c|c|c|c|c|}
\hline & \multicolumn{3}{|c|}{ Left wheel } & \multicolumn{3}{|c|}{ Right wheel } \\
\hline & \multicolumn{3}{|c|}{$\mathrm{LF}$} & \multicolumn{3}{|c|}{$\mathrm{RF}$} \\
\hline & $\mathrm{F}_{\mathrm{X} \text { max }}[\mathrm{N}]$ & $\mathrm{F}_{\mathrm{Y} \max }[\mathrm{N}]$ & $\mathrm{F}_{\mathrm{Zmax}_{\max }}[\mathrm{N}]$ & $\mathrm{F}_{\mathrm{X} \max }[\mathrm{N}]$ & $\mathrm{F}_{\mathrm{Ymax}}[\mathrm{N}]$ & $\mathrm{F}_{\mathrm{Zmax}}[\mathrm{N}]$ \\
\hline $\max$ & 1629.48 & 569.01 & 7679.95 & 1822.09 & 722.8 & 7863.34 \\
\hline $\min$ & -955.57 & -717.01 & -771.3 & -969.11 & -456.16 & -1096.48 \\
\hline$W$ & - & - & 1780.26 & - & - & 1960.21 \\
\hline \multirow[t]{3}{*}{$\mu$} & - & - & 0.23 & - & - & 0.25 \\
\hline & \multicolumn{3}{|c|}{ LR } & \multicolumn{3}{|c|}{$\mathrm{RR}$} \\
\hline & $\mathrm{F}_{\mathrm{X} \text { max }}[\mathrm{N}]$ & $\mathrm{F}_{\mathrm{Y} \max }[\mathrm{N}]$ & $\mathrm{F}_{\mathrm{Zmax}}[\mathrm{N}]$ & $\mathrm{F}_{\mathrm{X} \text { max }}[\mathrm{N}]$ & $\mathrm{F}_{\mathrm{Ymax}}[\mathrm{N}]$ & $\mathrm{F}_{\text {Zmax }}[\mathrm{N}]$ \\
\hline $\max$ & 2044.37 & 298.9 & 10318.8 & 2039.18 & 1062.44 & 11779.8 \\
\hline $\min$ & -3678.81 & -1111.65 & -566.79 & -3525.51 & -364.61 & -349.21 \\
\hline$W$ & - & - & 3843.1 & - & - & 3682.12 \\
\hline$\mu$ & - & - & 0.37 & - & - & 0.31 \\
\hline
\end{tabular}

However, in the case of the motion along the randomly uneven and icy road with the intensity of irregularities adopted at 1.5 (Table 10) the scenario from Table 8 repeated. The coefficient of adhesion for the front wheels was as low as before and on the rear wheels it decreased to 0.37 on the left and 0.31 on the right wheel. In this case the shorter distance obtained for configurations 4, 6 and 8 (Figures 5 and 6) should not be any surprise as these configurations caused the least adhesion.

It should also be remembered that the absolute values were used to calculate the coefficient of adhesion (equation (2)) as its value varies between 0 and 1.

\section{Conclusions}

From the presented results it can be concluded that the lateral phenomena, presented mainly through the lateral acceleration, can be strengthened on a randomly uneven road, especially when the surface is covered with ice.
The presented considerations show that the rearwheel drive, along with the engine located at the rear of a vehicle, can increase the value of the coefficient of adhesion for the rear wheels and decrease it for the front wheels. If the vehicle realized a different maneuver, e.g. taking a turn, this lateral motion could cause more severe consequences. In addition, if the engine were located at the front of the vehicle (under the bonnet) the motion, regardless of whether straightforward or taking a turn, could indicate oversteering.

Correctness of the results in this case seems to depend on the accuracy of measurements obtained in the simulations. However, with use of the real vehicles and the real measuring equipment, verification of the presented phenomena could be possible. It is also fair to mention that examination of the phenomena occurring between the road and the wheels may be one of the crucial factors for the road traffic safety.

One of the important indicators enabling qualitative analyzes can be examination of the vehicles' stability, based on analyses by the computer simulations and the vehicle models, as in some previous works by the author.

\section{References}

[1] AGOSTINACCHIO, M., CIAMPA, D., OLITA, S. The vibrations induced by surface irregularities in road pavements - a Matlab® approach. European Transport Research Review [online]. 2014, 6, p. 267-275. ISSN 18668887. Available from: https://doi.org/10.1007/s12544-013-0127-8

[2] BUZEMAN JEWKES, D. Vehicle acceleration and compartment intrusion for far-sided occupants v. near-sided occupants in frontal offset collisions. SAE Technical Paper Series [online]. 2003, 2003-01-0159. ISSN 0148-7191, eISSN 2688-3627. Available from: https://doi.org/10.4271/2003-01-0159

[3] GRAKOVSKI, A., PILIPOVECS, A. Dynamics of interaction between the road surface and vehicle's wheel in fibre-optic system for automatic weighing in motion of transport. Procedia Engineering [online]. 2017, 178, p. 5-12. ISSN 1877-7058. Available from: https://doi.org/10.1016/j.proeng.2017.01.052

[4] POKORSKI, J., SAR, H., RENSKI, A., Influence of exploitation conditions on anti-skid properties of tyres. Transport [online]. 2019, 34(4), p. 415-424. ISSN 1648-4142. Available from: https://doi.org/10.3846/ transport.2019.10426

[5] CHEN, CH., JIA, Y., WANG, Y., SHU, M. Non-linear velocity observer for vehicles with tyre-road friction estimation. International Journal of Systems Science [online]. 2018, 49(7), p. 1403-1418. Available from: https://doi.org/10.1080/00207721.2018.1454533 
[6] GIM, G., NIKRAVESH, P. E. An analytical model of pneumatic tire for vehicle dynamic simulations. Part I. International Journal of Vehicle Design. 1991, 11(6), p. 589-618. ISSN 0143-3369, eISSN 1741-5314.

[7] PROCHOWSKI, L., KOCHANEK, H., GIDLEWSKI, M., PUSTY, T. Analysis of the seasonal and regional variations in the accident hazard in Poland. In: Conference Urban Transport XXIII: proceedings [online]. 2017. Vol. 176. p. 441-452. Available from: https://doi.org/10.2495/UT170381

[8] RILL, G. Road vehicle dynamics: fundamentals and modeling. USA, CRC Press: 2011. ISBN 9781439838983.

[9] WALUS, K. J. Driver's strategy and braking distance in winter.: In: 21st International Scientific Conference Transport Means 2017: proceedings. 2017. Part 2. p. 505-509.

[10] WALUS, K. J., OLSZEWSKI Z. Analysis of tire-road contact under winter conditions. In: World Congress on Engineering WCE 2011: proceedings. 2011. Vol III.

[11] ZALEWSKI, J.. Impact of the selected motion parameters on some certain maintenance features of a motor vehicle / Wplyw wybranych parametrow ruchu na niektore cechy eksploatacyjne samochodu (in Polish). Poland: ITEEPIB, 2018. ISBN 9788377895160.

[12] ZHAO, J., ZHANG, J., ZHU, B. Development and verification of the tire/road friction estimation algorithm for antilock braking system. Mathematical Problems in Engineering [online]. 2014, 2014, 786492. ISSN 1024-123X, eISSN 1563-5147. Available from: https://doi.org/10.1155/2014/786492

[13] MUCKA, P. International roughness index thresholds based on whole-body vibration in passenger cars. Transportation Research Record Journal of the Transportation Research Board [online]. 2020, 2675(3), p. 1-16. ISSN 2169-4052. Available from: https://doi.org/10.1177/0361198120960475

[14] GONZALEZ, A., O'BRIEN, E. J., LI, Y.-Y., CASHELL, K. The use of vehicle acceleration measurements to estimate road roughness. Vehicle System Dynamics [online]. 2006, 46, p. 483-499. ISSN 1877-7058. Available from: https://doi.org/10.1016/j.proeng.2017.01.052

[15] LEVULYTE, L., ZURAULIS, V., SOKOLOVSKIJ, E. The impact of road roughness on the duration of contact between a vehicle wheel and road surface. Transport [online]. 2014, 29(4), p. 431-439. ISSN 1648-4142. Available from: https://doi.org/10.3846/16484142.2014.984330

[16] SOKOLOVSKIJ, E., PRENTKOVSKIS, O., PECELIUNAS, R., KINDERYTE-POSKIENE, J. Investigation of automobile wheel impact on the road border. The Baltic Journal of Road and Bridge Engineering [online]. 2007, 2(3), p. 119-123. ISSN 1822-427X. Available from: https://bjrbe-journals.rtu.lv/article/view/1822427X.2007.3.119-123

[17] KABANOVS, A., GARMORY, A., PASSMORE, M., GAYLARD, A. Investigation into the dynamics of wheel spray released from a rotating tyre of a simplified vehicle model. Journal of Wind Engineering and Industrial Aerodynamics [online]. 2019, 184, p. 228-246. ISSN 0167-6105, eISSN 1877-7058. Available from: https://doi. org/10.1016/j.jweia.2018.11.024

[18] STRAZOVEC, P., GERLICI, J., LACK, T., HARUSINEC, J. Innovative solution for experimental research of phenomena resulting from the wheel and rail rolling. Transportation Research Procedia [online]. 2019, 40, p. 906-911. ISSN 2352-1465. Available from: https://doi.org/10.1016/j.trpro.2019.07.127

[19] MIROSLAW, T., SZLAGOWSKI, J., ZAWADZKI, A., ZEBROWSKI, Z. Simulation model of an off-road four-wheel-driven electric vehicle. Proceedings of the Institution of Mechanical Engineers, Part I: Journal of Systems and Control Engineering [online]. 2019, 233, p. 1248-1262. ISSN 0959-6518. Available from: https://doi.org/10.1177/0959651818822399

[20] ZALEWSKI, J. On a certain approach towards the U-turn of a motor vehicle maneuver. In: Research and the future of telematics, communications in computer and information science [online]. Vol. 1289. MIKULSKI, J. (ed.). Germany, Springer: 2020. ISBN 978-3-030-59269-1, p. 354-367.

[21] GENTA, G. Motor vehicle dynamics. Modeling and simulation. World Scientific Publishing Company, 1997. ISBN 978-9810229115.

[22] GILLESPIE, T. D. Fundamentals of vehicle dynamics. Warrendale: Society of Automotive Engineers, 1992. ISBN 978-1-56091-199-9.

[23] JAZAR, R. N. Vehicle dynamics: theory and application [online]. Boston, MA: Springer, 2008. ISBN 978-0-38774243-4, eISBN 978-0-387-74244-1. Available from: https://doi.org/10.1007/978-0-387-74244-1

[24] MEYWERK, M. Vehicle dynamics. United Kingdom, Wiley: 2015, ISBN 9781118971352.

[25] PROCHOWSKI, L. Mechanics of motion / Mechanika ruchu (in Polish). Warsaw: WKL, 2016. ISBN 978-83-2061957-7.

[26] VENTURE, G., BODSON, P., GAUTIER, M., KHALIL, W. Identification of the dynamic parameters of a car. SAE Technical Paper Series [online]. 2003, 2003-01-1283. ISSN 0148-7191, eISSN 2688-3627. Available from: https://doi.org/10.4271/2003-01-1283

[27] EDDIE, R. Ice, ABS and temperature. SAE Technical Paper Series [online]. 1994, 940726. ISSN 0148-7191, eISSN 2688-3627. Available from: https://doi.org/10.4271/940724 
[28] HAUDUM, M., EDELMANN, J., PLOCHL, M., HOLL M. Vehicle side-slip angle estimation on a banked and low-friction road. Proceedings of the Institution of Mechanical Engineers Part D Journal of Automobile Engineering [online]. 2017, 232(12), p. 1584-1596. ISSN 0954-4070, eISSN 2041-2991. Available from: https://doi.org/10.1177/0954407017732852

[29] PEEIE, M. H. B., OGINO, H., OSHINOYA, Y. Skid control of a small electric vehicle with two in-wheel motors: simulation model of ABS and regenerative brake control. International Journal of Crashworthiness [online]. 2016, 21(5), p. 396-406. ISSN 1358-8265, eISSN 1754-2111. Available from: https://doi.org/10.1080/13588265.201 6.1147731

[30] ZHU, J. J., KHAJEPOUR, A., SPIKE, J., CHEN, S.-K., MOSHCHUK, N. An integrated vehicle velocity and tyre-road friction estimation based on a half-car model. International Journal of Vehicle Autonomous Systems [online]. 2016, 13(2), p. 114-139. ISSN 1471-0226, eISSN 1741-5306. Available from: https://doi.org/10.1504/ IJVAS.2016.078763

[31] PATEL, N., EDWARDS, C., SPURGEON, S. K. Tyre-road friction estimation - a comparative study. Journal of Automobile Engineering [online]. 2008, 222(D12), p. 2337-2352. ISSN 0954-4070, eISSN 2041-2991. Available from: https://doi.org/10.1243/09544070JAUTO859

[32] PAUL, D., VELENIS, E., HUMBERT, F., CAO, D., DOBO, T., HEGARTY, S. Tyre-road friction $\mu$-estimation based on braking force distribution. Proceedings of the Institution of Mechanical Engineers Part D Journal of Automobile Engineering [online]. 2018, 233(8), p. 2030-2047. ISSN 0954-4070, eISSN 2041-2991. Available from: https://doi.org/10.1177/0954407018765277

[33] VARAT, M. S., KERKHOFF, J. F., HUSHER, S. E., ARMSTRONG, C. D., SHUMAN, K. F. The analysis and determination of tire-roadway frictional drag. SAE Technical Paper Series [online]. 2003, 2003-01-0887. ISSN 0148-7191, eISSN 2688-3627. Available from: https://doi.org/10.4271/2003-01-0887

[34] KLEIN-PASTE, A., SINHA, N. K. Comparison between rubber-ice and sand-ice friction and the effect of loose snow contamination. Tribology International [online]. 2010, 43(5-6), p. 1145-1150. ISSN 0301-679X. Available from: https://doi.org/10.1016/j.triboint.2009.12.037

[35] MARTIN, D. P., SCHAEFER, G. F., Tire-road friction in winter conditions for accident reconstruction. SAE Technical Paper Series [online]. 1996, 960657. ISSN 0148-7191, eISSN 2688-3627. Available from: https://doi.org/10.4271/960657

[36] NAVIN, F., MACNABB, M., NICOLLETTI, C. Vehicle traction experiments on snow and ice. SAE Technical Paper Series [online]. 1996, 960652. ISSN 0148-7191, eISSN 2688-3627. Available from: https://doi.org/10.4271/960652 